\title{
PENDAMPINGAN PEMBELAJARAN TEMATIK DI LUAR KELAS BERBASIS MINAT BAKAT DI SDI RUTOSORO
}

\author{
Dek Ngurah Laba Laksana1), Ngurah Mahendra Dinatha'2), I Nyoman Try Upayogi ${ }^{3)}$ \\ 1)Pendidikan Guru Sekolah Dasar, ${ }^{2,3)}$ Pendidikan IPA \\ 1,2,3) Sekolah Tinggi Keguruan dan IImu Pendidikan Citra Bakti \\ 1)laba.laksana@citrabakti.ac.id, 2)ngurahm87@gmail.com, ${ }^{3)}$ upayogitry@gmail.com
}

\section{Histori artikel}

Received:

12 Maret 2020

Accepted:

14 April

Published:

15 April 2020

\begin{abstract}
Abstrak
Pengabdian ini bertujuan untuk memberikan aktivitas belajar di luar kelas berdasarkan minat untuk siswa sekolah dasar melalui pembelajaran tematik. Kegiatan ini dilakukan dengan metode pendampingan dan pembelajaran. Kegiatan ini melibatkan 119 siswa kelas I sampai kelas V dari SDI Rutosoro, Kabupaten Ngada, NTT. Kegiatan yang dilakukan antara lain, kegiatan akademik, kegiatan bidang olahraga, dan kegiatan bidang seni. Hasil kegiatan pengabdian yaitu. 1) Program ini dapat menumbuhkan minat dan rasa percaya diri siswa. Hal ini tampak dari sikap antusias dan ketekunan siswa dalam mengikuti berbagai aktivitas belajar. 2) Terjadi peningkatan kemampuan siswa dalam melakukan kegiatan yang menjadi fokus minat dan bakat masing-masing. Siswa menjadi lebih mahir dalam bidang yang mereka pilih. 3) Siswa memberikan tanggapan yang positif terhadap pelaksanaan program pendampingan tersebut.
\end{abstract}

Kata-kata kunci: pembelajaran tematik, pembelajaran luar kelas, pembelajaran berbasis minat 
Abstract. This Community Service program aimed to provide learning activities outside of classroom based on interests for elementary school students through thematic learning. This activity is carried out with assistance and learning methods. This activity involved 119 children from grade I to grade $\mathrm{V}$ from SDI Rutosoro, Ngada Regency. Activities undertaken included academic activities, sports activities, and arts activities. The results of service activities, i.e. 1) This program can foster student interest and confidence. This is evident from the enthusiastic attitude and perseverance of students in participating in various learning activities. 2) There is an increase in the ability of students to do activities that are the focus of their respective interests and talents. Students become more proficient in their chosen fields. 3) Students give positive responses to the implementation of the mentoring program.

Keywords: thematic learning, outside class learning, interest-based learning

\section{PENDAHULUAN}

Sebanyak 5.000-10.000 sekolah negeri dan swasta menerapkan sistem Full Day School (FSD) atau sekolah sehari penuh (Liputan6.com, 2017). Penerapan program ini, sejalan dengan kebijakan Menteri Pendidikan dan Kebudayaan.

Program FDS merupakan kebijakan pemerintah melalui Kementerian Pendidikan dan Kebudayaan. Kebijakan ini memberikan keleluasaan bagi sekolah untuk melaksanakan program FDS. FDS menerapkan suatu konsep dasar "Integrated-Activity" dan "IntegratedCurriculum". Model ini yang membedakan dengan sekolah pada umumnya. Dalam FDS semua program dan kegiatan siswa di sekolah, baik belajar, bermain, beribadah dikemas dalam sebuah sistem pendidikan. Penekanan pada FDS adalah siswa selalu berprestasi belajar dalam proses pembelajaran yang berkualitas yakni diharapkan akan terjadi perubahan positif dari setiap individu siswa sebagai hasil dari proses dan aktivitas dalam belajar (Addin, 2010).

FDS telah diimplementasikan di Kabupaten Ngada, Nusa Tenggara Timur. Istilah yang digunakan adalah Program Lima Hari Sekolah (LHS), program ini hampir sama dengan konsep FDS, yaitu mengintegrasikan aktivitas pembelajaran berbasis budaya lokal dalam bentuk kegiatan ektrakurikuler ke dalam pembelajaran (Baka, Laksana, dan Dhiu, 2019). Terdapat banyak jenis aktivitas yang dilakukan dalam penerapan program LHS, diantaranya adalah kegiatan non akademik seperti olahraga dan seni (Riwu dan Laksana, 2018).

Namun tidak bisa dipungkiri bahwa, program ini ada pada titik jenuh yang luar biasa. Riwu dan Laksana, 2018) menunjukkan bahwa aktivitas pembelajaran dalam pembelajaran dengan program LHS membuat siswa cepat lelah, kurang termotivasi. Selain itu, siswa dan orangtua menginginkan adanya kegiatan kreatif lainnya untuk menghilangkan rasa bosan dan jenuh tersebut.

Sebagai pendidik dan orang tua beranggapan bahwa bermain dan belajar adalah dua aktivitas yang berbeda. Bermain dapat menghabiskan waktu belajar anak, tetapi hal itu belum sepenuhnya benar. Jika kita bisa memahami dunia anak, kita dapat memasukkan konsep-konsep pembelajaran melalui kegiatan bermain yang berbasis pada minat anak. Minat dan kesukaan anak terhadap suatu kegiatan sangat mempengaruhi keinginan anak untuk melakukan kegiatan tersebut dengan sepenuh hati (Erhansyah, 2018). Oleh sebab itu 
menumbuhkan minat anak untuk melakukan sesuatu sangat penting dilakukan. Dengan kegiatan yang menarik minat anak, maka anak tidak bosan dan selalu antusias dalam mengikuti kegiatan tersebut. Aktivitas berbasis minat anak merupakan pegangan wajib bagi guru dan orang tua karena sangat mempengaruhi perkembangan anak (Permendikbud Nomor 37, 2018).

Piaget berpendapat bahwa perkembangan manusia dapat di gambarkan dalam konsep fungsi dan struktur. Fungsi merupakan mekanisme biologis bawaan yang sama bagi setiap orang atau kecenderungan biologis untuk mengorganisasi pengetahuan kedalam struktur kognisi, dan untuk beradaptasi kepada berbagai tantangan lingkungan. Tujuan dari fugsi-fungsi itu adalah menyusun struktur kognitif internal. Sementara struktur merupakan interaksi (saling berkaitan) system pengetahuan yang mendasari dan membimbing tingkah laku inteligen. Struktur kognitif diistilahkan dengan konsep skema, yaitu seperangkat keterampilan, pola-pola kegiatan yang fleksibel dan menarik minat anak untuk memahami lingkungan (Dasna, Laksana, dan Sudatha, 2015). Dengan memperhatikan minat soerang anak, maka konsep pembelajaran yang akan diberikan pastinya dapat diterima dengan mudah. Apalagi dengan adanya program full day school, maka minat seorang anak dalam belajar harus ditumbuhkan dan dikembangkan secara baik dan benar ((Permendikbud Nomor 37, 2018).

Program FDS juga diterapkan di Provinsi NTT, lebih khususnya di SDI Rutosoro, Kecamatan Golewa, Kabupaten Ngada. Analisis situasi pada sekolah-sekolah yang berada di SDI Rutosoro, sudah menerapkan pembelajaran FDS. Siswa di sekolah hanya belajar sesuai dengan materi tematik yang diberikan. Pada jam-jam sore, siswa cenderung merasa bosan dan lelah untuk mengikuti pelajaran. Siswa lebih banyak bermain dan melakukan kegiatan lain dari pada mengikuti pelajaran yang diberikan oleh guru. Oleh karena itu, perlu upaya melakukan pembelajaran di luar kelas namun tetap pada batasan minat dan bakat siswa.

Upaya tersebut dapat berupa pendampingan siswa dalam melaksanakan program FDS. Untuk itu, ditawarkan program pendampingan pembelajaran tematik di luar kelas berbasis minat dan bakat siswa di SDI Rutosoro yaitu program untuk memberikan kesempatan seluas-luasnya kepada peserta didik untuk melakukan sesuatu atas dasar kesukaan (minat).

Kegiatan pendampingan ini bertujuan untuk memberikan kegiatan berbasis keberminatan untuk siswa-siswa sekolah dasar dalam rangka menyukseskan program pembelajaran tematik di luar kelas berbasis minat dan bakat. Kegiatan ini dilakukan dengan metode pendampingan dan pembelajaran. Kegiatan yang dilakukan antara lain, kegiatan akademik, kegiatan bidang olahraga, dan kegiatan bidang seni. Berbagai kegiatan di atas, dilakukan berdasarkan tema yang sesuai saat pembelajaran terjadi. 
Terdapat tiga permasalahan yang dikaji dalam kegiatan pengabdian ini adalah sebagai berikut. (1) Apakah terjadi peningkatan motivasi belajar pada siswa melalui program pendampingan pembelajaran tematik di luar kelas berbasis minat dan bakat? (2) Apakah terjadi peningkatan hasil belajar pada siswa melalui program pendampingan pembelajaran tematik di luar kelas berbasis minat dan bakat? (3) Bagaimanakan tanggapan siswa terhadap kegiatan pendampingan pembelajaran tematik di luar kelas berbasis minat dan bakat?

Kegiatan ini mempunyai tiga tujuan pokok, tujuan dari kegiatan pendampingan pembelajaran tematik di luar kelas berbasis minat dan bakatadalah sebagai berikut. (1) Untuk meningkatkan motivasi belajar pada siswa melalui program pendampingan pembelajaran tematik di luar kelas berbasis minat dan bakat. (2) Untuk meningkatkan hasil belajar pada siswa melalui program pendampingan pembelajaran tematik di luar kelas berbasis minat dan bakat. (3) Untuk mengetahui tanggapan siswa, guru, orang tua terhadap kegiatan pendampingan pembelajaran tematik di luar kelas berbasis minat dan bakat.

\section{METODE PELAKSANAAN}

Secara umum, metode yang digunakan untuk mencapai tujuan pengabdian ini adalah metode pendampingan dan pembelajaran. Khalayak sasaran dalam kegiatan ini adalah siswa SD kelas I sampai kelas V yang berjumlah 119 orang. Lokasi pengabdian di SDI Rutosoro, Kecamatan Golewa, Kabupaten Ngada.

Kerangka umum pemecahan masalah melalui kegiatan pengabdian ini adalah. (1) Ketua dan anggota pengusul merumuskan rancangan kegiatan yang disusun berdasarkan minat siswa, persepsi keinginan orang tua, dan persepsi keinginan guru. (2) Siswa SD, orang tua, dan guru diajak berpartisipasi aktif melakukan keterlibatan langsung dalam memperoleh pengalaman dalam kegiatan seni, olahraga dan akademik. (3) Siswa SD, orang tua, dan guru diajak berdiskusi tentang pengalaman dan kendala yang dialami dalam mengikuti kegiatan yang ditawarkan.

Langkah-langkah pemecahan masalah tersebut dapat dikemukakan sebagai berikut. (1) Tim pengusul berkoordinasi dengan Kepala Dinas Pendidikan Pemuda dan Olahraga Kabupaten Ngada untuk mendiskusikan jadwal rencana kegiatan yang dirancang, mencakup program kegiatan, model pendampingan, waktu dan tempat pelaksanaan. (2) Peserta adalah guru sekolah dasar, orang tua siswa, dan siswa SD di Kecamatan Golewa, Kabupaten Ngada. (3) Waktu penyelenggaraan yaitu selama 2 minggu. (4) Tim penyusun program dari STKIP Citra Bakti menyiapkan perlengkapan berupa sarana kegiatan seperti peralatan olahraga, laptop, bahan-bahan kesenian, sementara pihak sekolah menyediakan tempat untuk melaksanakan program tersebut. 
Sejalan dengan cara pemecahan masalah yang ditempuh, maka sejumlah metode diterapkan dalam kegiatan ini. Metode yang digunakan dalam kegiatan ini adalah metode pendampingan dan pembelajaran. Deskripsi program dan indikator ketercapaian program disajikan dalam Tabel 1.

Tabel 1. Deskripsi Program dan Indikator Ketercapaian Program

\begin{tabular}{|c|c|c|c|}
\hline No & Program & $\begin{array}{c}\text { Deskripsi pelaksanaan } \\
\text { kegiatan }\end{array}$ & $\begin{array}{c}\text { Indikator } \\
\text { Ketercapaian }\end{array}$ \\
\hline 1 & $\begin{array}{l}\text { Pembelajaran } \\
\text { tematik di luar } \\
\text { kelas }\end{array}$ & $\begin{array}{l}\text { Kegiatan ini diisi dengan metode } \\
\text { pembelajaran di luar kelas. } \\
\text { Pemilihan seting luar kelas } \\
\text { dengan tujuan memberikan } \\
\text { lingkungan belajar yang } \\
\text { berbeda. }\end{array}$ & $\begin{array}{l}\text { a. Peningkatan } \\
\text { motivasi belajar } \\
\text { b. Peningkatan } \\
\text { hasil belajar pada } \\
\text { pembelajran } \\
\text { tematik }\end{array}$ \\
\hline 2 & $\begin{array}{l}\text { Pendampingan } \\
\text { kegiatan } \\
\text { olahraga yang } \\
\text { terkait tema }\end{array}$ & $\begin{array}{l}\text { Kegiatan ini dilakukan dengan } \\
\text { mendampingi siswa-siswi yang } \\
\text { akan mengikuti kegiatan } \\
\text { olahraga. Kegiatan ini } \\
\text { disesuaikan dengan tema } \\
\text { pembelajaran. }\end{array}$ & $\begin{array}{l}\text { Peningkatan teknik } \\
\text { dasar olahraga }\end{array}$ \\
\hline 3 & $\begin{array}{l}\text { Pendampingan } \\
\text { kegiatan seni } \\
\text { terkait tema }\end{array}$ & $\begin{array}{l}\text { Kegiatan ini dilakukan dengan } \\
\text { mendampingi siswa-siswi yang } \\
\text { akan mengikuti kegiatan seni. } \\
\text { Kegiatan ini disesuaikan dengan } \\
\text { tema pembelajaran. }\end{array}$ & $\begin{array}{l}\text { Peningkatan teknik } \\
\text { dasar dalam } \\
\text { membuat karya seni }\end{array}$ \\
\hline
\end{tabular}

\section{HASIL DAN PEMBAHASAN}

Hasil

Pengabdian ini dilaksanakan setiap hari sabtu, bertempat di SDI Rutosoro. Sasaran dari pengabdian ini adalah anak-anak kelas 1 sampai kelas 5 SD. Kegiatan pengabdian ini bertujuan untuk meningkatkan motivasi belajar pada siswa melalui program pendampingan pembelajaran tematik di luar kelas berbasis minat dan bakat.

Kegiatan pendampingan melibatkan tiga orang dosen dan 22 mahasiswa yang berasal dari Program Studi PGSD semester VI. Pendampingan kegiatan dilakukan secara serentak selama dua minggu dengan mengambil waktu jam 12.30 wita, setelah siswa selesai istirahat siang. Kegiatan tersebut berakhir tepat pada pukul 15.00 wita. Berikut adalah kegiatan pendampingan yang dilakukan disajikan pada Tabel 2.

\section{Tabel 2 Bentuk Kegiatan Pendampingan}

\begin{tabular}{|c|c|c|c|}
\hline No & Kelas & $\begin{array}{c}\text { Bentuk } \\
\text { kegiatan }\end{array}$ & Hasil \\
\hline 1 & I & $\begin{array}{l}\text { Pembelajaran } \\
\text { tematik di luar } \\
\text { kelas }\end{array}$ & $\begin{array}{l}\text { Pembelajaran dilakukan di tempat ibadah. } \\
\text { Pembelajaran adalah dengan permainan jam. Di } \\
\text { mana siswa membentuk kelompok kemudian } \\
\text { melingkar. Dua orang siswa diminta untuk } \\
\text { menjadi jarum jam dan satunya lagi menjadi } \\
\text { jarum menit. Kegiatan ini bertujuan untuk } \\
\text { mengenalkan konsep waktu. }\end{array}$ \\
\hline 2 & II & Pembelajaran & Pembelajaran dilakukan di teras sekolah. \\
\hline
\end{tabular}




\begin{tabular}{|c|c|c|c|}
\hline No & Kelas & $\begin{array}{c}\text { Bentuk } \\
\text { kegiatan }\end{array}$ & Hasil \\
\hline & & $\begin{array}{l}\text { tematik di luar } \\
\text { kelas }\end{array}$ & $\begin{array}{l}\text { Pembelajaran menggunakan bahan bahan kertas. } \\
\text { Di mana siswa diajak untuk bermain origami. } \\
\text { Berbagai bentuk permaianan origami dilakukan } \\
\text { oleh siswa dan dibantu oleh mahasiswa. }\end{array}$ \\
\hline
\end{tabular}

\begin{tabular}{|c|c|c|c|}
\hline 3 & III & $\begin{array}{l}\text { Pembelajaran } \\
\text { tematik di luar } \\
\text { kelas }\end{array}$ & $\begin{array}{l}\text { Pembelajaran dilakukan di lapangan sepak bola. } \\
\text { Siswa diajak untuk bermain tanah jejak. Dimana } \\
\text { siswa berjalan dengan peta yang telah didesain } \\
\text { oleh mahasiswa. Setiap peta ada lokasi yang } \\
\text { mereka harus berhenti dan memecahkan } \\
\text { permasalahan yang diberikan. }\end{array}$ \\
\hline 4 & IVA & $\begin{array}{l}\text { Pembelajaran } \\
\text { tematik di luar } \\
\text { kelas }\end{array}$ & $\begin{array}{l}\text { Pembelajaran dilakukan di lapangan voli Siswa } \\
\text { diajak untuk berlatih mengenai teknik dasar } \\
\text { dalam bermain voli. }\end{array}$ \\
\hline 5 & IVB & $\begin{array}{l}\text { Pembelajaran } \\
\text { tematik di luar } \\
\text { kelas }\end{array}$ & $\begin{array}{l}\text { Pembelajaran dilakukan di lapangan voli. Siswa } \\
\text { diajak untuk berlatih mengenai teknik dasar } \\
\text { dalam bermain voli. }\end{array}$ \\
\hline 6 & V & $\begin{array}{l}\text { Pembelajaran } \\
\text { tematik di luar } \\
\text { kelas }\end{array}$ & $\begin{array}{l}\text { Pembelajaran dilakukan di aula. Siswa diajak } \\
\text { untuk melakukan gerakan tarian. Tarian daerah } \\
\text { (tari Ja'i dan Dero) }\end{array}$ \\
\hline
\end{tabular}

Bentuk-bentuk kegiatan terdokumentasi dalam kegiatan yang dilakukan pada pendampingan pembelajaran tematik di luar kelas berbasis minat dan bakat di SDI Rutosoro. Dokumentasi kegiatan disajikan pada Gambar 1.

\section{Pembahasan}

Sesuai dengan rencana, program "Pendampingan Pembelajaran Tematik di Luar Kelas Berbasis Minat Bakat di SDI Rutosoro" ini dievaluasi dengan melihat proses kcgiatan dan hasil yang dicapai melalui perkembangan dan evaluasi kegiatan setia sabtu, hasilnya dapat dikemukakan berikut ini.

1. Tumbuhnya minat dan motivasi siswa untuk mengikuti program "Pendampingan Pembelajaran Tematik di Luar Kelas Berbasis Minat Bakat di SDI Rutosoro". Hal ini terlihat dari respon siswa yang sangat tinggi dalam mengikuti kegiatan tersebut.

2. Kemampuan siswa dalam melakukan kegiatan yang menjadi fokus minat dan bakat masing-masing meningkat pesat setiap minggunya. Siswa menjadi lebih mahir dalam bidang yang mereka pilih yaitu peningkatan motivasi dan hasil belajar, peningkatan teknik dasar olahraga, dan peningkatan teknik dasar melukis atau menggambar dan bernyanyi.

3. Tanggapan siswa positif terhadap pelaksanaan program "Pendampingan Pembelajaran Tematik di Luar Kelas Berbasis Minat Bakat di SDI Rutosoro". Tanggpan positif ini 
ditandai dengan terjadi proses interaksi aktif di berbagai kegiatan yang sudah dilakukan. Siswa sangat senang dan menyukai program ini. 

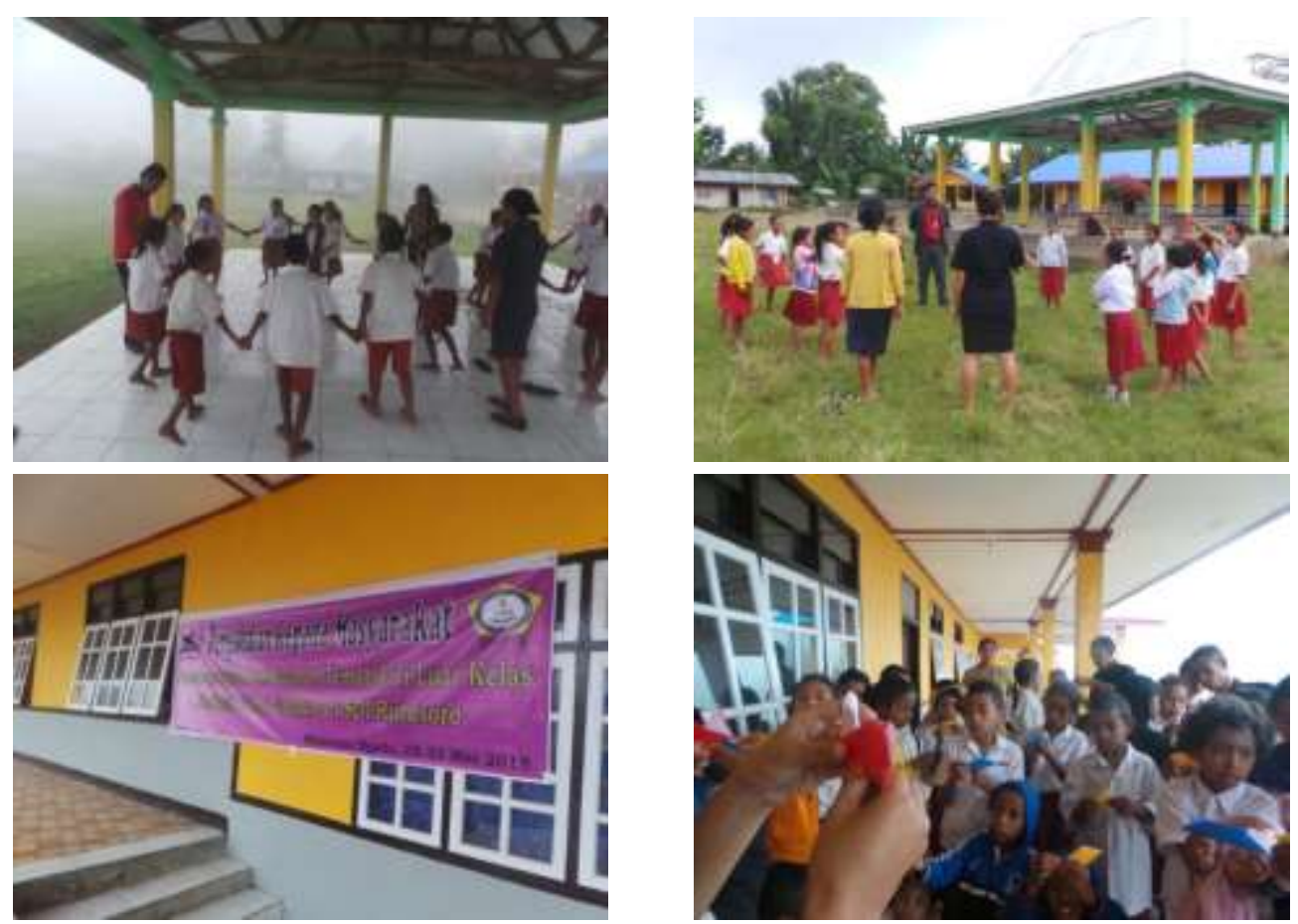

Gambar 1. Kegiatan Pendampingan Pembelajaran Tematik di Luar Kelas

Hal yang diutamakan dalam pendampingan di luar kelas adalah pengaturan jadwal mata pelajaran dan pendalaman. Sebagian waktunya digunakan untuk program-program pembelajaran yang suasana informal, tidak kaku, menyenangkan bagi siswa dan membutuhkan kretifitas dan inovasi dari guru. Pendampingan di luar kelas menerapkan suatu konsep dasar "integrated-activity" dan "integrated-curriculum". Model ini yang membedakan dengan sekolah pada umumnya.

Dalam pendampingan ini semua program dan kegiatan siswa di sekolah, baik belajar, bermain, beribadah dikemas dalam sebuah sistem pendidikan. Titik tekan pendampingan ini adalah siswa selalu berprestasi belajar dalam proses pembelajaran yang berkualitas ditandai dengan perubahan positif dari setiap individu siswa sebagai hasil dari proses dan aktivitas dalam belajar di luar kelas (Laksana dan Dinatha, 2017; Laksana dan Seso, 2019).

Adapun prestasi belajar yang dimaksud terletak pada tiga ranah, yaitu. (1) Prestasi yang bersifat kognitif seperti kemampuan siswa dalam mengingat, memahami, menerapkan, mengamati, menganalisa, membuat analisa dan lain sebagianya. (2) Siswa dapat menyebutkan dan menguraikan pelajaran minggu lalu, berarti siswa tersebut sudah dapat dianggap memiliki prestasi yang bersifat kognitif. Siswa dapat dianggap memiliki prestasi yang bersifat afektif, jika anak sudah bisa bersikap untuk menghargai, serta dapat menerima dan menolak terhadap suatu pernyataan dan permasalahan yang sedang mereka hadapi. (3) 
Prestasi yang bersifat psikomotorik yaitu kecakapan eksperimen verbal dan nonverbal, keterampilan bertindak dan gerak, aspek intelektual, fisik, sosial dan emosional.

Hasil pendampingan siswa dalam melaksanakan program belajar di luar kelas memberikan kesempatan seluas-luasnya kepada peserta didik untuk melakukan sesuatu atas dasar kesukaan (Laksana dan Dinatha, 2017). Program ini diawali dengan survei keberminatan siswa SD terhadap tiga pokok bidang kegiatan utama, yaitu bidang seni, olahraga, dan akademik. Bidang seni dijabarkan lagi ke dalam beberapa sub bidang, antara lain: lukis, gambar, menyanyi, intrumen musik, tari. Sub bidang olahraga dibagi menjadi sepakbola, voli, beladiri. Sementara sub bidang akademik, antara lain: matematika, IPA, IPS, Bahasa Inggris, Bahasa Indonesia, PKn, Calistung.

\section{KESIMPULAN}

Kesimpulan kegiatan pengabdian "Pendampingan Pembelajaran Tematik di Luar Kelas Berbasis Minat Bakat di SDI Rutosoro" adalah sebagai berikut.

1) Program ini telah mampu menumbuhkan minat dan rasa percaya diri siswa. Hal ini tampak dari keantusiasan dan ketekunan siswa dalam mengikuti kegiatan sampai akhir.

2) Kemampuan siswa dalam melakukan kegiatan yang menjadi fokus minat dan bakat masing-masing meningkat pesat setiap minggunya. Siswa menjadi lebih mahir dalam bidang yang mereka pilih.

3) Tanggapan siswa positif terhadap pelaksanaan program "Pendampingan Pembelajaran Tematik di Luar Kelas Berbasis Minat Bakat di SDI Rutosoro". Telah terjadi proses interaksi aktif di berbagai kegiatan yang sudah dilakukan. Siswa sangat senang dan menyukai program ini.

Saran yang penulis berikan berdasarkan hasil pelaksanaan dan evaluasi kegiatan adalah sebagai berikut.

1) Perlu adanya sosialisasi terhadap beberapa SD yang berada di wilayah Kecamatan Golewa untuk menerapkan program "Pendampingan Pembelajaran Tematik di Luar Kelas Berbasis Minat Bakat" sehingga mampu menumbuhkan minat dan bakat siswa.

2) Program "Pendampingan Pembelajaran Tematik di Luar Kelas Berbasis Minat Bakat di SDI Rutosoro" hendaknya terus dilaksanakan di sekolah sasaran oleh guru tetap di SD tersebut. Sehingga siswa lebih fokus dalam menekuni minat dan bakatnya masingmasing 


\section{DAFTAR PUSTAKA}

Addin, A. (2010). Penerapan sistem full day school sebagai upaya untuk meningkatkan kualitas pendidikan di mi al-qamar nganjuk. [Online]. Diterima melalui http://lib.uinmalang.ac.id/files/thesis/fullchapter/06110206.pdf, pada 3 Januari 2019.

Baka, N.A., Laksana, D.N.L., \& Dhiu, K.D. (2019). Konten dan konteks budaya lokal ngada sebagai bahan ajar tematik di sekolah dasar. Journal of Education Technology, 2 (2), 46-55

Dasna, I.W., Laksana, D.N.L.,\& Sudatha, G.W. (2015). Desain dan model pembelajaran inovatif dan interatif. Tangerang: Universitas Terbuka

Erhansyah. (2018). Urgensi penerapan pembelajaran berbasis minat siswa SMP. BRILIANT: Jurnal Riset dan Konseptual, 3(4), 385-391

Laksana, D.N.L. \& Dinatha, N.M. (2017). Sabtu bersama kita: Sebagai pilot project fullday school. Laporan Pengabdian (tidak diterbitkan). Program Studi PGSD, STKIP Citra Bakti.

Laksana, D.N.L. \& Riwu, I.U. (2017). Inovasi aktivitas belajar dalam menanamkan nilai karakter di sekolah dasar yang menerapkan program full day school. Prosiding Seminar Nasional Save Our Teachers for Character Building. Bajawa, NTT: 18-20 November 2017, 189-194.

Permendikbud Nomor 37 Tahun 2018 tentang Perubahan Atas Permendikbud Nomor 24 Tahun 2016 tentang kompetensi inti dan kompetensi dasar pelajaran pada kurikulum 2013 pada pendidikan dasar dan pendidikan menengah. Jakarta: Kemendikbud.

Laksana, D.N.L., \& Seso, M.A. (2019). Desain pembelajaran konstekstual spirit meda mazi di sd kelas rendah. Journal of Education Technology, 2 (1),1-5.

Liputan6.com. (2017). 10.000 Sekolah daftar terapkan full day school. [Online]. Diterima melalui https://www.liputan6.com/news/read/2891656/10000-sekolah-daftar-terapkanfull-day-school. (30 Maret 2019). 